and a half million tons. Shipowners have the choice of a dozen types of Diesel engines, such as the Burmeister and Wain, the Werkspoor, the Sulzer, the Beardmore, the Cammellaird-Fullagar, and the Doxford, some being of the four-cycle and some of the two-cycle type. These engines differ in many respects, but all have the same characteristic in being more economical than the steam engine. Mention may also be made of the experiment being carried out with the Still engine, in which the top of the piston is acted upon by the pressure of the burning gases, while the underside is acted upon by the pressure of steam raised in a small boiler heated by the exhaust gases.

In addition to the advocates of the steam turbine and the Diesel engine there is yet another school of engineers which believes the future of marine propulsion lies with what is known as the electric drive. This system has been developed far more in America than on this side of the Atlantic, and all recent capital ships for the United States Navy have electric transmission. In these vessels oil-fired boilers supply steam to Curtis turbines driving electric generators which supply current to the motors on the propeller shafts. The general adoption of such a system, it was pointed out by Prof. Abell, may lead to remarkable alterations in the plans of ships, as the engine-rooms can be placed between decks or otherwise as thought most suitable. A turbine-electric plant involves the use of boilers, turbines, condensers, generators, and motors, but an alternative is to replace the boilers, turbines, and condensers by Diesel engines. The various proposals have been reviewed in his book on "Electric Ship Propulsion" by Commander S. M. Robinson, of the United States Navy. He there divides both naval and mercantile vessels into classes, and states which type of machinery he considers most suitable. For the cargo tramp he would have Diesel engine and electric drive, for other merchant vessels and for large war vessels steam turbines and electric drive, while for destroyers and light cruisers he would retain geared turbine.

From the foregoing it will be seen that the whole practice of marine engineering is, as it were, in the melting-pot, and what the standard form of marine propulsion will be in the future is difficult to see. Given trustworthiness, it is economy which has the deciding influence; economy in weight, economy in space, economy in upkeep, economy in fuel. What the continual striving after economy has done in the past can be judged by the fact that, fifty years ago, to convey a hundred tons of cargo a mile required 18 to $20 \mathrm{lbs}$. of coal ; to-day the same result is obtained with I $\frac{1}{2}$ to 2 lbs of oil. Finality was thought by some to have been reached when the compound engine was introduced. Great advances have been made since then. But while it may not be possible to effect revolutions on the scale of the past, the time is far distant when improvements will be impossible.

\title{
Obituary.
}

\section{Sir JAMES Dewar, F.R.S.}

SIR JAMES DEWAR died at the Royal Institu- tion, in his eighty-first year, on March 27. He had been working in his laboratory until late on the night of March 20 and was taken ill in the early hours of the following morning.

Our scientific edifice is thus suddenly deprived of one of its main pillars; we shall not easily appraise the loss. The immensity and sustained originality of his genius, the service he rendered to our civilisation, can be but insufficiently appreciated outside the small circle of intimates who witnessed his work and, having penetrated through the thick mask of modesty and reticence which he habitually wore, could disregard his sometimes brusque, inconsequent manner, his volcanic, torrential outbursts of picturesque criticism-knowing these to be but the expression of an extreme intensity of conviction and purpose and an overmastering honesty. At heart he was full of human sympathy, a most gentle and lovable nature-but the presbyter was ever in him.

As an experimentalist Dewar stood alone: there has never been a greater, probably none so great. Science loses in him a worker of peculiar breadth of originality, a most fascinating character; how much the world is poorer it little knows. He was of a type--almost primitive, in this competitive age, in honesty of purpose--now fast becoming extinct, a lineal descendant of his great countryman, Joseph Black, in no way less successful than his predecessors, Young, Davy and Faraday, in adding to the reputation these pioneers created for the Royal Institution as a centre of scientific discovery and invention. He also made it a social centre of great attraction and cast over it an æsthetic spell which it had not previously known. Davy sought society but did not fashion it. Dewar could rarely be persuaded into it but became himself noted as a host, on account of his own great conversational power and the beauty of the surroundings he accumulated: his home was the salon of science and art.

As a lad Dewar met with an accident which, in after life, he regarded as fortunate. Falling through the ice, he contracted rheumatic fever and was long unable to attend school but became intimate with the village joiner. In those days, Scotland having been in close commercial relation with Italy, fiddles abounded and the lad had musical tastes. With his own hands he made several violins, from one of which we heard the sweetest of music conjured forth, by a skilled lady performer, on the occasion of the celebration of his golden wedding, less than two years ago. He always regarded the training he thus received as the most important part of his education and the foundation of the great manual dexterity which he displayed in his work and his lectures. He often complained to me of the sad lack of such ability in the modern student. His master in chemistry was Lyon Playfair. Dewar was one of the few who could appreciate Playfair's great scientific ability and were able to gauge the loss of his early deflexion into the tortuous paths of politics, which Playfair himself regretted in later life. The two men became fast friends and Playfair was long chief admirer of his pupil's brilliant ability. At one time, I believe, Playfair endeavoured to secure his entry in to the dyestuff industry ; had Dewar's masterful energy been operative 
in this field our position to-day might well have been one of unrivalled supremacy.

Dewar also came under Kekulés influence at Ghent. Körner was then assistant in the laboratory and Dewar and he became associated in all sorts of devilry-Körner being a great practical joker and Dewar a wild young Scot. The stamp of the organic chemist was thus burnt into his soul at a critical period-the spell of Körner's marvellous preparative skill being cast over him ; he often referred to the time. His mathematical and physical proclivities were thus broadened and he became a complete chemist in spirit. The Dewar benzene-formula, though an imperfect expression of modern knowledge - paper formulæ are but shorthand expressions of character-has not yet lost its vogue. His name is also written in the pyridine chapter. He and I were the first users of sulphuric chlorhydrol, $\mathrm{SO}_{3} \mathrm{HCl}$. $\mathrm{He}$ did notable work before he came south-first with Tait, in which he laid the foundation both for his later application of a vacuum in preventing heat exchanges and of charcoal as an absorbent; and with $\mathrm{M}^{\prime}$ Kendrick, with whom he carried out an important inquiry on the physiological action of light.

In 1875 he was appointed Jacksonian professor of natural experimental philosophy in the University of Cambridge and became the colleague of Prof. Liveing. He never carried out the prime duty of his office-the discovery of a cure for the gout-though in early days he sought unsuccessfully for the qualification which might have helped in the work; unfortunately, he only spoilt his digestion and so, in later years, was perforce an extraordinarily careful liver.

Two years after his appointment at Cambridge he also became Fullerian professor of chemistry at the Royal Institution, London. He had twice lectured there previously on the work he had done with M'Kendrick. The second lecture (March 3I, I876), his trial trip, was probably the most carefully prepared, certainly the most logical, discourse he ever delivered; I well recollect how fascinated some of us were by it.

Even if it be possible for a man to serve two masters, the task becomes beyond human power when ghosts aid one of them. As an artist, Dewar had the innate belief of primitive man in ghosts and in the Royal Institution laboratory, miserable as was the accommodation it afforded, the ghosts of Davy and Faraday were ever about him. Let us hope that his successor will be gripped by thoughts of the trinity which Dewar's entry into their Valhalla has established. To have served the Institution honourably, in a way to justify mention in history on a par with them, is an achievement he, in his modesty, scarcely contemplated as possible and yet he ever aimed at it. The feeling that he had so much exceeded Faraday's period of office and not only maintained but also steadily improved the quality of his work, I have reason to think, was year by year a more and more powerful mainspring of action in the indomitable fight against circumstances which he waged during these late bitter times of strife. He was a terrible pessimist.

To return to Cambridge, he found there no tradition of practical achievement to influence him. His colleague Liveing and the Master of his College. Dr. Porter, were perhaps the only men who fathomed his outstanding ability. The crudity of youth was still upon him and the free manners of a Scottish University were not those of conventional Cambridge-his sometimes imprecatory style was not thought quite comme il faut by the good. No attempt was made to tame him or provide means for the development of his special gift of manipulative skill. Yet he soon began to exercise an influence which probably has had more to do with the marvellous recent advance of the Chemical School at Cambridge than is commonly supposed. The fine volume of collected researches in spectroscopy which Prof. Liveing and he published a few years ago, is a memorial not merely to their activity but of the example they set as exact observers in a field which, at that time, was in sore need of cautious workers. And the work he did in London had its reflex effect at Cambridge.

Dewar was not great as a teacher. His mind was of too original and impatient a type. He never suffered fools gladly and students are too apt to be foolish-at our old Universities, even to ape the part of superior beings. His forte lay in directing competent hands, not in forming them. He worked himself and through skilled assistants, not through pupils. He was violently impatient of failure in manipulation and his work was almost entirely manipulatory. He, therefore, never created a school. The pity of it is that circumstances were such that he never had a properly large staff. That he accomplished so much with the assistance of the few able men who have aided him is proof of his exceptional skill as a director. It is unfortunate that the Davy-Faraday laboratory was not, from the beginning, organised on lines which would have placed its resources in his hands rather than at the disposal of undirected individual workers; it is a grievous fact that he leaves no followers trained to use his incomparable methods.

Nominally a chemist, Dewar's work lay in fields of his own creation, not borderlands but regions before uncultivated. He was no mere experimentalist but an artist to his finger-tips and in nose, tongue, eye and ear - a perfect judge of Wein, Weib and Gesang, giving to these terms their widest significance; music came next to science in his affections.

Though deeply read and a great lover of poetry and literature, he lacked the gift of ready literary expression--except in his letters and conversation-and was often an incoherent lecturer, yet his lectures were the most masterly and fascinating displays ever witnessed. He set a standard which has made the Royal Institution table remarkable throughout the world. Faraday was celebrated for the simplicity of his style-Dewar is to be thought of on account of the daring of his displays, the wonderful refinement and appositeness of his demonstrations, all most carefully arranged and rehearsed in advance. He was a great scientific actor, playing plays with the most thrilling of plots and entirely original special scenery for each performance. His manner, his brogue, even his impatience, gave a peculiar charm to the impression he produced; but you did well to have been behind the scenes if you wished to gather the full meaning of his message. His demonstrations were unique in character; few realise the infinite loving care he devoted to their preparation. In their simplicity they were often profound. I can never NO. 2788 , VOL. I I I ] 
forget the impression I received when I first saw him burn diamond under liquid air-the gradual accretion of the carbon dioxide snow-shower and the blueing of the fluid by ozone, also demonstrated by the iodine test. Then the rapid uprush of the mercury in a barometer-tube full of air when the tube was cooled with liquid hydrogen : it all but knocked the top off. Or again, the production of ozone at the surface of solid oxygen by the impact of ultra-violet radiations. At such moments-and there were many such--the heart beat with joy at the significance of his feats of inspiration.

To the outside world Dewar is known as the man who liquefied oxygen and other gases and as the inventor of the vacuum flask - his name will probably go down the years on this last account. It is due to his memory that this should be spoken of henceforward as the Dewar flask: it was his free gift to the public; had he protected and developed the invention he might have amassed a fortune and fully endowed his chair.

The real value of his. work on gases, apart from the impetus it gave to the industrial use of liquefied air in particular, is to be found in the many new directions in which he developed the art of inquiry at low temperatures. Perhaps the most illuminating is the inquiry into the heat capacities of the elements at the temperature of boiling liquid hydrogen: the discovery of a periodic variation, corresponding with that in atomic volume at ordinary temperatures, is not only surprising but may well prove to be of profound significance in the future interpretation of atomic properties in terms of electronic structure.

Like his great predecessor, Dewar leaves a mass of material to be interpreted by his successors. Unfortunately, he was all too careless in placing his work on record. Like Turner, he painted for his own pleasure, to give expression to his genius-but too often did not put the picture aside for a Ruskin to glory over.

In two essays printed in the Proceedings of the Royal Institution-Cone on the "Charcoal Vacuum Septennate" (I909), the other on the "High Vacuum Septennate" (r9r 7 )-I have briefly summarised his later and chief work at low temperatures; in the latter I also briefly review his work generally as Fullerian professor up to I9I7. These essays may serve to guide students. With him, however, we lose a vast unrecorded experience.

Of late years he had returned to a first love-the soap film: it saved his life and was his solace, keeping him from utter despair during the War. He only left it to go to his last bed of sickness. It is to be feared the record of the work is a very imperfect one. Those who were at his last lecture on "Soap Films as Detectors," on the opening of the Friday evenings this year, will not forget the occasion. He was obviously in physical distress and feeble but mentally as alert as ever; the artist was never more to the fore. His appeal was that made in Cory's beautiful Incantation.

My sun is stooping westward. Entrancèd Dreamer haste,

There's fruitage in my garden that I would have thee taste.

But he was the "entrancèd Dreamer"-the fruitage he gave us to taste was lovely; nothing so exquisite had before been brought in such perfect form under the public eye. He recalled Young to us; then, playing with a delicate pencil of air upon his liquid lute, he made visible, in hues of the rainbow, the multitude of its melodies, during over a third of his hour. He had never before lingered so long over a single demonstration. He knew that we were gazing upon no mere play of colour but upon a dance of the molecules such as is at the root of life--and death!

How many of us were serious listeners to the message he felt was to be his last, that he was most bent on making, to his urgent appeal on behalf of the Institution which he had served so long, so well, so nobly-was to serve even up to the moment of his death? He will have worked to no purpose if his appeal be unregarded. The fate and future of science in our country is at stake: nothing less. The Egyptians, thousands of years ago, could make worthy provision for the soul of a boy king of eighteen who had done nothing. Surely our civilisation cannot be so backward, so thoughtless, so unmindful of its present peril, that it will not properly maintain an altar and a virile priesthood to keep alive the memory of men like Davy, Faraday and Dewar in the one way they would all wish-by extending their works in the service of mankind, to its salvation.

H. E. A.

\section{Prof, A. S. Butler.}

Arthur Stanley Butler, emeritus professor of natural philosophy in the University of St. Andrews, died at his residence at Upper Redpits, Marlow, Bucks, on March 3. He was a worthy scion of a family distinguished in the church, in education, in letters, and in athletics. His grandfather, the Rev. Dr. George Butler, senior wrangler, was the distinguished headmaster of Harrow; one uncle was Dr. Henry Montague Butler, master of Trinity College, Cambridge, whose charm of manner he possessed; another uncle was the well-known Arthur G. Butler, Dean of Oriel, a not undistinguished athlete. His father, the Rev. George Butler, D.D., at one time vice-principal of Cheltenham College, was latterly Canon of Winchester ; his mother, Mrs. Josephine Butler, an author, philanthropist, and active pioneer in higher education of women.

Prof. Butler was born on May I7, I854; educated at Cheltenham and at Exeter College, Oxford (of which his father-a Hertford scholar in his day-had been fellow), where he obtained first class in Moderations (mathematics) and first-class honours in the Final School. After further study at Oxford, at Cambridge in the mechanical workshop under Prof. James Stuart, and at Liverpool, he was appointed to the chair at St. Andrews in $r 880$.

Prof. Butler's experience, especially at Cambridge, made him realise how desirable it is that students of natural philosophy should carry out some experimental work in addition to attending lectures and class demonstrations. But like his predecessor. Prof. Swan, he had the difficulties of want of accommodation and suitable apparatus. In the first year at St. Andrews a special grant provided him with some necessary apparatus, and in a few years he succeeded in obtaining a good practical laboratory well furnished: and then all his students were required to do some practical work.

As a lecturer Prof. Butler was highly successful. His lectures to the ordinary class were characterised

NO. 2788 , VOL. I I I] 